\title{
7,7-ジシアノベンゾキノンメチドと 1,3-シクロヘキサジエンとの無触媒重合反応機構
}

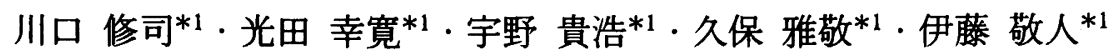

（受付 2003 年 12 月 1 日·審査終了 2004 年 1 月 7 日）

\begin{abstract}
要 旨 7,7-シシシアノベソゾキノンメチド（CQM）と1,3-シクロヘキサジエン（CHD）との無触媒重 合を行い,へキサン不容部および可溶部より得られた生成物を解析した。へキサン不溶部は CQM と CHD との交互共重合体であった。 その交互共重合体中の CHD 単位は 1,2-と 1,4-結合した構造を有して いた. ヘキサン可溶部には未反応の CQM と CHD のほかに CQM と CHD の Diels-Alder 付加体が存在し た. $\mathrm{CQM}$ と CHD との仕込み組成を変化させても, 交互共重合体が生成し，モノマー仕込み比 $1 / 1$ の時 に高収率でポリマーが得られた，反応中間体を調査するために，酢酸および 2,2,6,6-テトラメチルピペリ シンー1ーオキシル（TEMPO）存在下での無触媒反応を検討した. 酷酸存在下では生成物の構造, 収率に 大きな変化は認められなかった. 一方, TEMPO 存在下では TEMPOによる捕捉物が得られた。これらの 結果から, CQM と CHD との無触媒重合はラシカル中間体を経由する機構であることが明らかとなった.
\end{abstract}

\section{1 緒言}

電子受容性オレフィンモノマーと電子供与性オレフィ ンモノマーとの無触媒重合では, 交互共重合体をたは電 子供与性オレフィンモノマーの単独重合体が得られる. この無触媒重合機構を説明するために Hall らは, 両モ ノマー間でシララシカルをたは双性イオンテトラメチレン 中間体が形成され, シラシカル中間体から交互共重合体 が, 双性イオン中間体から電子供与性オレフィンモノ マーの単独重合体が生成するという “bond-forming initiation theory” を提唱している1,2). この考えは電子供 与性オレフィンと電子受容性キノシメタン類との無触媒 重合にも拡張されている3) 9). たとえば, 7,7,8,8-テト ラシアノキノジタン（TCNQ）は, スチレンとの無触 媒重合でジラシカル中間体を経由した交互共重合が進行 し, 一方, ビニルエーテル類では双性イオン中間体を経 由したビニルエーテルの単独重合が進行するとされてい る.しかし，これまでにその無触媒重合が検討されてき たキノシメタン類は TCNQ などの対称置換キノジメタ ン類であり, 非対称置換キノシメタン類に関する研究例 はほとんとない，非対称置換キノシメタンを使用すれば 付加方向を含め, 無触媒重合反応機構についてより多く の情報が得られるとの考えから, 最近筆者らは非対称置 換電子受容性キノシメタンである 1-(2,2-ジチル-1,3-

*1 三重大学工学部分子素材工学科（亚514-8507 津市上浜町 1515)
シオキサン-4,6-ジオン-5-イリデン)-4-(シシシアノメチ レン)-2,5-シクロヘキサシェン (QM-1) とp-メトキシ スチレン（MeOSt）との無触媒重合を検討した。その 結果, 双性イオン中間体を経由したシクロブタン環形成 に続くメタセシス反応により，三置換キノシメタンであ る 7-(4-メトキシフェニル)-8,8-シシシアノキノシメタン （QM-2）とメチレンメルドラム酸が生成し，QM-2 と QM-1 がラシカル機構で共重合する特異な反応機構であ ることを見いたしだ）ささらに，QM-1（第一還元電 位 : $\left.E_{1}=+0.13 \mathrm{~V}\right)$ より電子受容性が弱い7,7-シジア ベンソキノンメチド $(\mathrm{CQM})\left(E_{1}=-0.04 \mathrm{~V}\right)$ と MeOSt との無触媒重合では, 双性イオン中間体を経由 した交互共重合が進行することを見いたした ${ }^{11)}$. 本研究 ではこれまでにほとんど検討されていないジエン系モ ノマーに注目し, CQM と1,3-シクロヘキサシェン （CHD）との無触媒重合を行い, その反応機構について 調査した.<smiles>CC(C#N)=C1C=CC(=O)C=C1</smiles>

CQM

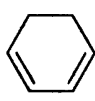

CHD
Scheme 1. 


\section{2 実 験}

\section{1 試薬}

CQM は Hyatt と Kurtak の方法に従って調製した ${ }^{12)}$. CHD は市販品（和光純薬工業(株)製）を減圧蒸留によ り精製した. クロロホルムは水素化カルシウムを用いて 蒸留することにより精製した. 酢酸（和光純薬工業(株） 製）と 2,2,6,6-テトラメチルピペリシンー1-オキシル （TEMPO : シグマアルドリッチジャパン(株)製）は市 販品をそのまま用いた。

\section{$2.2 \mathrm{CQM}$ と CHD との無触媒重合}

カラスアンプル管に CQM (235 mg) をはかり取り, 次に CHD $(121 \mathrm{mg})$ を溶解したクロロホルム溶液 $8 \mathrm{~mL}$ を加えた. freeze-thaw 3 回繰返し脱気封管後, $60^{\circ} \mathrm{C}$ で 24 時間反応した. 反応溶液を大過㮃のへキサンに注 ぎ，ヘキサン不溶部と可溶部に分けた.ヘキサン不溶部 はクロロホルムに溶解し, 再度大過㮃のへキサンに沈殿 させることを綝返して精製した後, 真空下で乾燥させ, 白色粉末固体を得た.へキサン可溶部は溶媒を留去後, シクロロメタンを溶離液としたシリカゲルカラムクロマ トグラフィーにより末反応 CQM を除去し, さらにシク ロロメタン/ベンゼン混合溶媒 $(1 / 1(\mathrm{vol} / \mathrm{vol}))$ を溶離 夜としたシリカゲルカラムクロマトグラフィーにより黄 色オイル（1）を得た. CQM とCHDとの仕込み組成 を変えた場合も重合後, 同様の処理を行った.

白色粉末固体：収量 $275.0 \mathrm{mg}(77.2 \%)$; IR ( KBr) $v_{\mathrm{C}-\mathrm{H}}$ 2965, $v_{\mathrm{C} \equiv \mathrm{N}} 2258, v_{\mathrm{C}=\mathrm{C}} 1517, v_{\mathrm{C}-\mathrm{O}} 1262 \mathrm{~cm}^{-1} ;{ }^{1} \mathrm{H}$ NMR $\left(\mathrm{CDCl}_{3}\right) \delta: 7.39(\mathrm{~m}, 4 \mathrm{H}), 6.94(\mathrm{~m}, 4 \mathrm{H}), 6.23 \sim 5.52(\mathrm{~m}$, $4 \mathrm{H}), 4.93,4.77(\mathrm{~s} \times 2,2 \mathrm{H}), 3.00,2.86(\mathrm{~s} \times 2,2 \mathrm{H}), 2.34 \sim$ $1.56(\mathrm{~m}, 8 \mathrm{H}) ;{ }^{13} \mathrm{C} \mathrm{NMR}\left(\mathrm{CDCl}_{3}\right) \delta: 158.1$ (Ar), 157.3 (Ar), $134.3(=\mathrm{CH}), 130.9(=\mathrm{CH}), 129.2(\mathrm{Ar}), 128.0$ (Ar), $126.1(=\mathrm{CH}), 121.7(=\mathrm{CH}), 116.6(\mathrm{Ar}), 114.5$ $(\mathrm{CN}), 71.6(>\mathrm{CH}-\mathrm{O}), 68.3(>\mathrm{CH}-\mathrm{O}), 46.4\left(\mathrm{C}(\mathrm{CN})_{2}\right)$, $45.6(>\mathrm{CH}), 44.8(>\mathrm{CH}), 27.4\left(\mathrm{CH}_{2}\right), 26.1\left(\mathrm{CH}_{2}\right)$, $23.8\left(\mathrm{CH}_{2}\right), 20.5\left(\mathrm{CH}_{2}\right)$; Anal. Calcd for alternating copolymer $\left(\left(\mathrm{C}_{15} \mathrm{H}_{12} \mathrm{~N}_{2} \mathrm{O}\right)_{\mathrm{n}}\right): \mathrm{C}, 76.25 ; \mathrm{H}, 5.12 ; \mathrm{N}, 11.86$; O, 6.77. Found: C, 75.70; H, 5.13; N, 12.01.

黄色オイル（1）: 収量 $47.3 \mathrm{mg} （ 13.3 \%) ; \mathrm{IR} （ \mathrm{KBr}$ ） $v_{\mathrm{C}-\mathrm{H}} 2954, v_{\mathrm{C} \equiv \mathrm{N}} 2226, v_{\mathrm{C}=\mathrm{O}} 1671, v_{\mathrm{C}=\mathrm{C}} 1538, v_{\mathrm{C}-\mathrm{O}} 1250$ $\mathrm{cm}^{-1} ;{ }^{1} \mathrm{H} \mathrm{NMR}\left(\mathrm{CDCl}_{3}\right) \delta: 7.45(\mathrm{~d}, J=10.23 \mathrm{~Hz}, 1 \mathrm{H})$, $6.35(\mathrm{~d}, J=10.23 \mathrm{~Hz}, 1 \mathrm{H}), 6.22(\mathrm{~m}, 2 \mathrm{H}), 3.61(\mathrm{~d}, J=$ $8.58 \mathrm{~Hz}, 1 \mathrm{H}), 3.21(\mathrm{~s}, 1 \mathrm{H}), 2.97(\mathrm{~s}, 1 \mathrm{H}), 2.88$ (dd, $J=$ $2.64,8.58 \mathrm{~Hz}, 1 \mathrm{H}), 1.95 \sim 1.75(\mathrm{~m}, 2 \mathrm{H}), 1.48 \sim 1.35(\mathrm{~m}$, $2 \mathrm{H}) ;{ }^{13} \mathrm{C} \mathrm{NMR}\left(\mathrm{CDCl}_{3}\right) \delta: 197.5(\mathrm{C}=\mathrm{O}), 170.8(>\mathrm{C}$ $=), 138.3(=\mathrm{CH}), 137.7(=\mathrm{CH}), 132.6(=\mathrm{CH}), 133.9$ $(=\mathrm{CH}), 111.9(\mathrm{CN}), 111.0(\mathrm{CN}), 87.0\left(=\mathrm{C}(\mathrm{CN})_{2}\right)$, $48.3(\mathrm{CH}), 43.5\left(\mathrm{CH}_{2}\right), 39.6\left(\mathrm{CH}_{2}\right), 35.9(\mathrm{CH}), 27.2$ (CH), $22.7(\mathrm{CH})$; Anal. Calcd for $\mathrm{C}_{15} \mathrm{H}_{12} \mathrm{~N}_{2} \mathrm{O}: \mathrm{C}, 76.25$;
H, 5.12; N, 11.86; O, 6.77. Found: C, 75.13; H, 5.05; N, 11.39 .

2.3 TEMPO 存在下での CQM と CHD との無触媒 重合

ガラスアンプル管に CQM (235 mg) と TEMPO (119 $\mathrm{mg}$ )を取り，CHD（121 mg）を溶解したクロロホルム 溶液 $8 \mathrm{~mL}$ を加えた. freeze-thaw 3 回繰返し脱気封管 後, $60^{\circ} \mathrm{C}$ で 24 時間反応した. 反応溶液を大過剩のへキ サンに注ぎ, ヘキサン不溶部と可溶部に分けた. ヘキサ ン不溶部はクロロホルムに溶解し, 再度大過剩のへキサ ンに沈殿させることを繰返して精製した後，真空下で乾 燥させ，白色粉末固体を得た。へキサン可溶部は溶媒を 留去後, クロロホルムを溶離液としたシリカゲルカラム クロマトグラフィーにより橙色オイル (132.7 mg) を得 た.この橙色オイルはさらにシクロロメタンを溶離液と したシリカゲルカラムクロマトグラフィーで処理するこ とにより，2 種類の淡橙色オイル（2）と（3）に分けた.

白色粉末固体 : 収量 $58.4 \mathrm{mg}(12.3 \%)$; IR (KBr): $v_{\mathrm{O}-\mathrm{H}}$ $3427, v_{\mathrm{C}-\mathrm{H}} 2978, v_{\mathrm{C} \equiv \mathrm{N}} 2261, v_{\mathrm{C}=\mathrm{C}} 1530, v_{\mathrm{N}-\mathrm{O}} 1381, v_{\mathrm{C}-\mathrm{O}}$ $1285 \mathrm{~cm}^{-1} ;{ }^{1} \mathrm{H}$ NMR $\left(\mathrm{CDCl}_{3}\right) \delta: 7.40(\mathrm{~m}, 4 \mathrm{H}), 6.92(\mathrm{~m}$, $4 \mathrm{H}), 6.41 \sim 5.48(\mathrm{~m}, 4 \mathrm{H}), 4.92,4.78(\mathrm{~s} \times 2,2 \mathrm{H}), 3.00$, $2.86(\mathrm{~s} \times 2,2 \mathrm{H}), 2.36 \sim 1.55(\mathrm{~m}, 8 \mathrm{H}), 1.45(\mathrm{~s}), 1.10(\mathrm{~s})$. Anal. Calcd for $\mathrm{H}-(\mathrm{CQM}-\mathrm{CHD})_{3}$-TEMPO $\left(\mathrm{C}_{54} \mathrm{H}_{55} \mathrm{~N}_{7}\right.$ $\left.\mathrm{O}_{4}\right)$ : C, 74.89; H, 6.40; N, 11.32; O, 7.39. Found: C, $74.79 ; \mathrm{H}, 6.22 ; \mathrm{N}, 11.48 ; M_{\mathrm{n}}=710$.

淡橙色オイル（2）: 収量 $88.6 \mathrm{mg}(18.6 \%)$; IR ( $\mathrm{KBr})$ : $v_{\mathrm{O}-\mathrm{H}} 3444, v_{\mathrm{C}-\mathrm{H}} 2932, v_{\mathrm{C} \equiv \mathrm{N}} 2256, v_{\mathrm{C}=\mathrm{C}} 1513, v_{\mathrm{N}-\mathrm{O}} 1360$, $v_{\mathrm{C}-\mathrm{O}} 1277 \mathrm{~cm}^{-1} ;{ }^{1} \mathrm{H} \mathrm{NMR}\left(\mathrm{CDCl}_{3}\right) \delta: 7.38(\mathrm{~d}, J=8.24$ $\mathrm{Hz}, 2 \mathrm{H}), 6.92(\mathrm{~d}, J=8.57 \mathrm{~Hz}, 2 \mathrm{H}), 6.32(\mathrm{~m}, 1 \mathrm{H}), 5.61$ $(\mathrm{m}, 1 \mathrm{H}), 4.36(\mathrm{~m}, 1 \mathrm{H}), 2.93(\mathrm{~m}, 1 \mathrm{H}), 2.30(\mathrm{~m}, 1 \mathrm{H})$, $1.92(\mathrm{~m}, 1 \mathrm{H}), 1.58 \sim 1.26(\mathrm{~m}, 8 \mathrm{H}), 1.11(\mathrm{~s}, 12 \mathrm{H}) ;{ }^{13} \mathrm{C}$ NMR $\left(\mathrm{CDCl}_{3}\right) \delta: 156.9$ (Ar), $136.9(\mathrm{Ar}), 128.0(=\mathrm{CH})$, $123.4(\mathrm{Ar}), 121.9(\mathrm{CN}), 116.9(\mathrm{Ar}), 114.2(\mathrm{CN}), 77.7$ $(>\mathrm{CH}-\mathrm{O}), 59.8\left(\mathrm{C}\left(\mathrm{CH}_{3}\right)_{2}\right), 47.0\left(\mathrm{CH}_{2}\right), 46.7\left(\mathrm{CH}_{2}\right)$, $40.1\left(\mathrm{CH}_{3}\right), 34.2\left(\mathrm{C}(\mathrm{CN})_{2}\right), 28.7(\mathrm{CH}), 24.4\left(\mathrm{CH}_{2}\right)$, $20.4\left(\mathrm{C}\left(\mathrm{CH}_{3}\right)_{2}\right), 17.0\left(\mathrm{CH}_{2}\right)$; Anal. Calcd for $\mathrm{H}-(\mathrm{CQM}-$ CHD) $)_{1}$ TEMPO $\left(\mathrm{C}_{24} \mathrm{H}_{31} \mathrm{~N}_{3} \mathrm{O}_{2}\right): \mathrm{C}, 73.25 ; \mathrm{H}, 7.94 ; \mathrm{N}$, 10.68; O, 8.13. Found: C, 74.13; H, 7.86; N, 10.23.

淡橙色オイル（3）: 収量 $23.1 \mathrm{mg}(4.9 \%)$; IR（KBr): $v_{\mathrm{O}-\mathrm{H}} 3438, v_{\mathrm{C}-\mathrm{H}} 2938, v_{\mathrm{C} \equiv \mathrm{N}} 2256, v_{\mathrm{C}=\mathrm{C}} 1513, v_{\mathrm{N}-\mathrm{O}} 1360$, $v_{\mathrm{C}-\mathrm{O}} 1277 \mathrm{~cm}^{-1}$; ${ }^{1} \mathrm{H}$ NMR $\left(\mathrm{CDCl}_{3}\right) \delta: 7.39(\mathrm{~d}, J=8.24$ $\mathrm{Hz}, 2 \mathrm{H}), 6.85$ (d, $J=8.57 \mathrm{~Hz}, 2 \mathrm{H}), 6.24$, (m, $1 \mathrm{H}), 5.61$ $(\mathrm{m}, 1 \mathrm{H}), 4.07(\mathrm{~m}, 1 \mathrm{H}), 2.74(\mathrm{~m}, 1 \mathrm{H}), 2.11(\mathrm{~m}, 1 \mathrm{H})$, $1.72(\mathrm{~m}, 1 \mathrm{H}), 1.75 \sim 1.23(\mathrm{~m}, 8 \mathrm{H}), 1.03(\mathrm{~s}, 12 \mathrm{H})$.

\section{4 測定}

${ }^{1} \mathrm{H}$ およ゙ ${ }^{13} \mathrm{C}$ NMR スペクトルはクロロホルム $-d$ 中, 日本電子(株)製 JNM-EX270を用いて測定した。 IR スペクトルは Jasco Corp. 製 IR-700により測定し 
た. GPC 測定は TSK gel G2500H 8 （粒径：10 $\mu \mathrm{m}$ ，分 子量範囲 : $\left.1.0 \times 10^{2} \sim 2.0 \times 10^{4}\right)$ と TSK gel G3000H （粒径： $10 \mu \mathrm{m}$, 分子量範团 : $1.0 \times 10^{2} \sim 6.0 \times 10^{4}$ ） カラ ムを装着した Jasco Corp. 製 PU-2080 を用い，Jasco Corp. 製 UV-2075（254 nm）により検出した．溶離液 としてテトラヒドロフラン（THF）を用い, 流速 1.0 $\mathrm{mL} / \mathrm{min}$ で測定した. ポリマーの数平均分子量はポリス チレン換算で求めた. 融点測定および元素分析はそれぞ れ Yanaco LID Co., Ltd. 製 MP-S3, Yanaco LID Co., Ltd. 製 CHN Corder MT-5 を用いた.

\section{3 結果および考察}

\subsection{CQM と CHD との無触媒重合}

$\mathrm{CQM}$ と CHD との無触媒重合を 3 種類の異なるモノ マー仕込み比 $(\mathrm{CQM} / \mathrm{CHD}=1 / 2,1 / 1,2 / 1)$ でクロロ ホルム中, $60^{\circ} \mathrm{C}, 24$ 時間行った. また $\mathrm{CQM}$ と CHD と のモノマー仕込み比を $1 / 1$ と一定とし, 酢酸または TEMPO を添加した場合についても検討した．それらの 結果を Table 1 にまとめて示す．いずれの場合も CQM と CHD を混合すると同時に，系は CQM の特改的な橙 色から褐色へと変化した. CQM と CHD との間で電荷 移動錯体が生成していることを示している. 反応後, 反応 生成物をへキサン不溶部と可溶部に分別し，それぞれの 構造について ${ }^{1} \mathrm{H},{ }^{13} \mathrm{C} N M R ， I R ，$ 元素分析および GPC により解析した.

仕込み組成を変えた場合（entry 1〜3）のへキサン不 溶部はいずれの系においても白色粉末固体が得られ， GPCより求めたそれらの分子量は $1400 〜 1700$ であっ た. 収量および分子量はモノマー仕込及比 $1 / 1$ で最大と なり，1/2 および $2 / 1$ では低下した．これは交互共重合 が起きると報告されているメトキシアレンと TCNQ と の無触媒重合と同じ傾向であった ${ }^{13)}$ 、へキサン不溶部の IR スペクトルには 2965, 2258, 1517, $1262 \mathrm{~cm}^{-1}$ にれ それ脂肪族 $\mathrm{C}-\mathrm{H}$ 伸縮， $\mathrm{C} \equiv \mathrm{N}$ 伸縮， $\mathrm{C}=\mathrm{C}$ 伸縮， $\mathrm{C}-\mathrm{O}$ 伸縮に帰属されるピークが観測され， $\mathrm{CQM}$ ユニットと CHD ユニットの両方を含む共重合体であることを示し
ている.モノマー仕込み比 1/1 (entry 2) で得られた白 色粉末固体の ${ }^{1} \mathrm{H}$ NMR スペクトルを Figure 1 に示す. 7.6 6.7 ppm のピークは CQM ユニットの芳香族プロ トン $(a, b), 6.3 \sim 5.5 \mathrm{ppm}$ は CHD ユニットの $\mathrm{C}=\mathrm{C}$ 結 合由来のメチンプロトン $(c), 5.0 \sim 4.7 \mathrm{ppm}$ は $\mathrm{CHD}$ ב ニットの酸素に隣接したメチンプロトン $(d, e), 3.1 \sim$ $2.7 \mathrm{ppm}$ は CHD ユニットのシシシアノメレン基に隣接 したメチンプロトン $(f, g), 2.4 \sim 1.4 \mathrm{ppm}$ は CHD ב ニットのメチレンプロトン（h）にそれぞれ帰属され， $\mathrm{CQM}$ と CHD の交互共重合体であると考えられる。 た，酸素に隣接したメチンプロトンは, メトキシ基とイ ソプロピル基を有する類似したシクロヘキセン化合物 ${ }^{14)}$ のケミカルシフト值を参考に, 低磁場側の $d$ を 1,4-結 合した CHD ユニット，高磁場側の $\boldsymbol{e}$ を1,2-結合した CHD ユニットにそれぞれ弗属し，その積分比から CHDの 1,2-結合単位 $(\mathbf{X})$ と 1,4-結合単位 (Y) の比 を算出したところほほほ $\mathbf{X}: \mathbf{Y}=2: 3$ であった。さら に, 元素分析より求めた共重合体中の $\mathrm{CQM}$ ユニット含 量は CQM とCHD との仕込み組成に関係なく，いずれ もほほ $50 \mathrm{~mol} \%$ \% あり，仕込み比が $1 / 1$ の場合に収量 および分子量が最大となることから，CQM と CHD と の無触媒重合において, 交互共重合が進行していると考 えられる. ヘキサン可溶部の ${ }^{1} \mathrm{H}$ NMR 測定を行ったと ころ, 未反応の $\mathrm{CQM}$ と CHD 以外の生成物によるピー クが観測された. シリカゲルカラムクロマトグラフィー により処理し, 黄色オイル（1）を分離した（収量 : entry $1=25.1 \mathrm{mg}(6.4 \%)$, entry $2=47.3 \mathrm{mg}(13.3 \%)$, entry $3=24.2 \mathrm{mg}(7.4 \%))$. その黄色オイル（1）は, ${ }^{1} \mathrm{H},{ }^{13} \mathrm{C}$

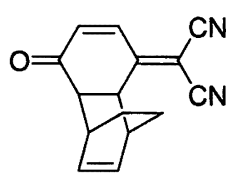

Diels-Alder adduct (1)

Scheme 2.

Table 1. Spontaneous polymerizations of $\mathrm{CQM}$ with $\mathrm{CHD}^{\mathrm{a})}$

\begin{tabular}{|c|c|c|c|c|c|c|c|c|c|c|c|}
\hline \multirow{2}{*}{ Entry } & \multicolumn{3}{|c|}{ Monomer feed } & \multirow{2}{*}{ Additive } & \multirow{2}{*}{$\begin{array}{l}\text { Polymer } \\
\left.\text { yield }{ }^{\mathrm{b}}\right) \\
(\mathrm{mg})\end{array}$} & \multicolumn{3}{|c|}{$\begin{array}{c}\text { Elemental } \\
\text { analysis }\end{array}$} & \multirow{2}{*}{$\begin{array}{c}\text { Copolymer } \\
\text { composition } \\
\text { CQM } \\
\text { mol\% }\end{array}$} & \multirow{2}{*}{$\begin{array}{c}\text { Unit } \\
\text { ratio }^{\text {c) }} \\
\mathbf{X} / \mathbf{Y}\end{array}$} & \multirow{2}{*}{$M_{\mathrm{n}}^{\mathrm{d})}$} \\
\hline & $\begin{array}{l}\text { CQM } \\
(\mathbf{m g})\end{array}$ & $\begin{array}{l}\text { CHD } \\
\text { (mg) }\end{array}$ & $\begin{array}{l}\mathrm{CQM} \\
\mathrm{mol} \%\end{array}$ & & & $\mathrm{C} \%$ & $\mathrm{H} \%$ & N\% & & & \\
\hline 1 & 157 & 161 & 33.3 & - & 193 & 75.29 & 5.01 & 11.90 & 50.3 & $21 / 29$ & 1430 \\
\hline 2 & 235 & 121 & 50.0 & - & 275 & 75.70 & 5.13 & 12.01 & 51.1 & $20 / 30$ & 1700 \\
\hline 3 & 314 & 81 & 66.7 & - & 196 & 75.00 & 4.91 & 12.11 & 51.5 & $22 / 28$ & 1400 \\
\hline 4 & 235 & 121 & 50.0 & $\mathrm{AcOH}^{\mathrm{e})}$ & 254 & 74.86 & 4.96 & 12.33 & 52.7 & $23 / 27$ & 1430 \\
\hline 5 & 235 & 121 & 50.0 & TEMPO $^{f)}$ & 58 & 74.79 & 6.22 & 11.48 & 51.4 & $19 / 31$ & 710 \\
\hline
\end{tabular}

a) Temp.: $60^{\circ} \mathrm{C}$; time: $24 \mathrm{~h}$; solvent: chloroform $(8 \mathrm{~mL})$. b) Hexane-insoluble part. c) Ratio of 1,2- (X) and 1,4-(Y) polymerization units of CHD in copolymer, determined by ${ }^{~} \mathrm{H}$ NMR. d) Determined by GPC (polystyrene standards). e) Acetic acid, $0.5 \mathrm{~mL}$. f) $119 \mathrm{mg}$. 


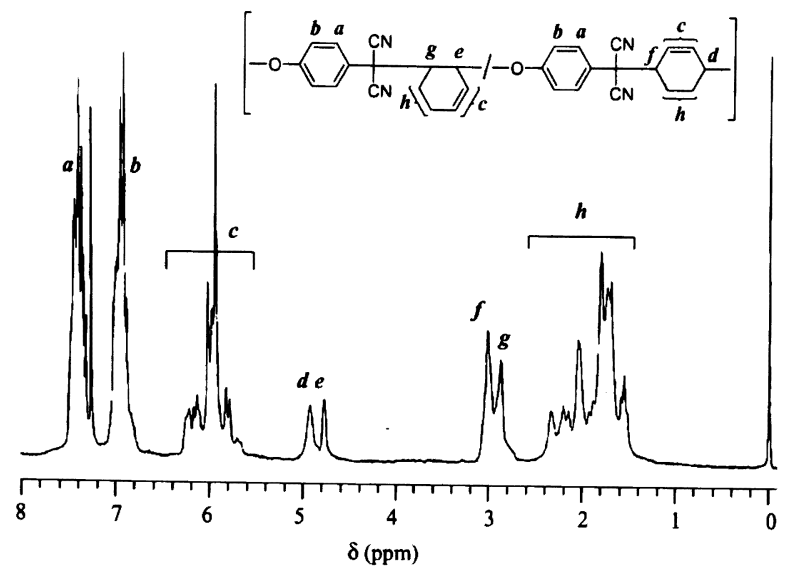

Figure 1. ' ${ }^{\mathrm{H}} \mathrm{NMR}$ spectrum of hexane-insoluble product obtained by the spontaneous polymerization of CQM with CHD (entry 2).

NMR，IR 測定および元素分析より，Diels-Alder 反応に よる $\mathrm{CQM} と \mathrm{CHD}$ との $[4+2] \pi に よ る 1: 1$ 付加体 (1) であった ${ }^{15)}$.

CQM と CHD との無触媒重合反応における活性種に ついての知見を得るために，イオン重合禁止剂として酭 酸, ラジカル重合禁止剤としてTEMPO を添加して, $\mathrm{CQM}$ とCHD との仕込み比 1/1，クロロホルム中, $60^{\circ} \mathrm{C}, 24$ 時間で無触媒重合を行った. イオン重合禁止剤 である酢酸を添加した系 (entry 4) では, ヘキサン不 溶部として交互共重合体が得られ，その収量および分子 量には酢酸無添加の系（entry 2) と著しい違いは観察 されなかった．また，へキサン可溶部についても，酢酸 無添加の系と同様に，末反応モノマーと Diels-Alder 付 加体（1）が得られた。一方, ラシカル重合禁止剤であ るTEMPO を添加した系 (entry 5) では, ヘキサン不 溶部の収量およびその分子量に明らかに低下が見られ， TEMPO 添加による重合の抑制効果が認められた。

Figure 2 に示すように，へキサン不溶部として得られた 白色粉末固体の ${ }^{1} \mathrm{H}$ NMR スペクトルにおいては，1.1 および $1.4 \mathrm{ppm} に$ TEMPO に帰属されるピークが観測 され，交互共重合体の末端に TEMPO が付加している ことを示している．また，元素分析の結果は重合度か3 3 の交互共重合体の末端に TEMPO が付加した構造の計 算値とほほ一致した。へキサン可溶部の ${ }^{1} \mathrm{H}$ NMR スペ クトルには, 未反応モノマーと Diels-Alder 付加体（1) 以外の生成物によるピークが確認されたので，クロロホ ルムを溶離液としたシリカゲルカラムクロマトグラフ ィー処理により, 橙色オイルを得た. この橙色オイルを さらにシクロロメタンを溶離液としたシリカゲルカラム クロマトグラフィーで処理することにより，2 種類の淡 橙色オイル（(2): $88.6 \mathrm{mg}(18.6 \%)$ および (3): 23.1 mg (4.9\%).) を得た。多量に得られた淡橙色オイル（2)

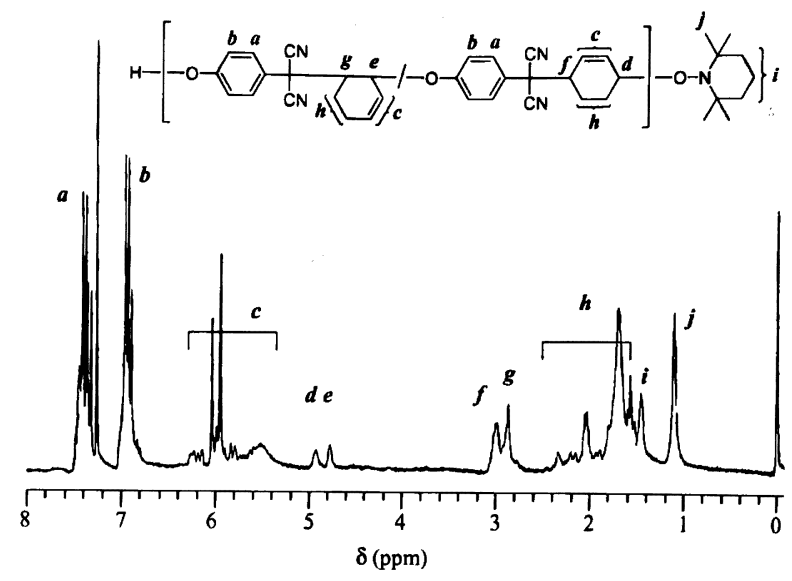

Figure 2. ' ${ }^{\prime} \mathrm{H}$ NMR spectrum of hexane-insoluble product obtained by the spontaneous polymerization of CQM with CHD in the presence of TEMPO (entry 5 ).

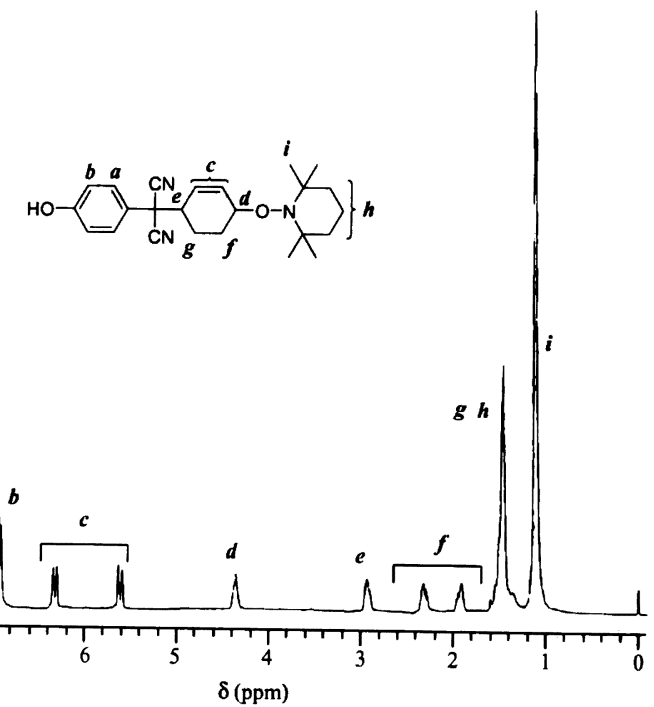

Figure 3. 'H NMR spectrum of a pale orange oil (2) isolated from the hexane-soluble product obtained by the spontaneous polymerization of CQM with CHD in the presence of TEMPO.

の ${ }^{1} \mathrm{H}$ NMR スペクトルを Figure 3 に示す．各ピークは $\mathrm{CQM}$ ユニットの芳香族プロトン $(\boldsymbol{a}, \boldsymbol{b}), 1,4$-結合した CHD ユニットのメチン $(\boldsymbol{c}, \boldsymbol{d}, \boldsymbol{e})$ およびメチレンプロ トン $(f, g)$, TEMPO ユニットのメチレン $(h)$ および メチルプロトン $(i)$ に帰属できる.したがって淡橙色 オイル（2）は図中に示した CQM/CHD/TEMPO の 1 : 1: 1 付加体に帰属でき, ${ }^{13} \mathrm{C}$ NMR, IR，および元素分 析む，その構造を支持している．淡橙色オイル（3）は CHD ユニットのメチン $(4.07,2.74 \mathrm{ppm})$ およびメチ レンプロトン $(2.11,1.72 \mathrm{ppm})$ のピーク位置が異なる のみで，ほかのピークはほほ淡橙色オイル（2）と同じ であることから，CHDが 1,2-結合した 1:1:1付加体 
に州属できる. ${ }^{13} \mathrm{C}$ NMR, IR むその構造を支持している.

\section{2 無触媒重合機構}

CQM と CHD との無触媒重合では, 仕込み組成によ らす゚ヘキサン不榕部として交互共重合体（重合度（DP） =6〜7）が得られ，ヘキサン可溶部からは CQM と CHD との Diels-Alder 付加体が得られた。この無触媒 重合反応系にイオン重合禁止剂である酢酸を添加した場 合, ヘキサン不溶部, 可溶部ともに, 酢酸無添加の系と 同様の交互共重合体および Diels-Alder 付加体が得られ たのに対し，ラジカル重合禁止剤である TEMPOを添 加した場合，交互共重合体の収量および分子量に大きな 低下が見られ，末端にTEMPOを有する交互共重合体 $(\mathrm{DP}=3)$ が得られた.ささらにへキサン可溶部から $\mathrm{CQM} / \mathrm{CHD} / \mathrm{TEMPO}$ の $1: 1: 1$ 付加体が単離された.

これらの結果は, CQM と CHD との無触媒重合反応が 双性イオン中間体ではなく, ジラジカル中間体を経由し た機構で進行していることを示唆している.すなわち, Scheme 3 に示すようにCQM とCHD との無触媒反応 では, Diels-Alder 付加体とシラシカル中間体の両方が 生成し, シラシカル中間体から交互共重合体が生成する と考えられる. シラシシカル中間体の重合の際に，CQM と結合した CHD ユニットの 2-位または 4-位にシラシ カル中間体のフェノキシラジカルが付加することで重合 が進行するが，立体障害の少ない4-位の方が結合しゃ すいために，1,4-結合した CHD 単位（Y）が 1,2-結合 単位（X)よりも過剩に含まれる交互共重合体（X:Y =2:3）が生成すると考えられる。C CQM/CHD/ TEMPOの $1: 1: 1$ 付加体生成において，1,4-結合した CHD 単位を有する付加体（2）と 1,2一結合した CHD 単 位を有する付加体（3）の生成比が 4:1 であることから も支持される.
先に, CQM とMeOSt との無触媒重合では, 双性イ オン中間体を経由した交互共重合が進行することを報告 した ${ }^{11)}$. 一方, 今回の CQM と CHD との無触媒重合で は, シラシカル中間体を経由した交互共重合が進行し た. Hall らは “bond-forming initiation theory”におい て, 電子受容性モノマーと電子供与性モノマーの無触媒 重合では, 電子供与性の強いモノマーの場合, 双性イオ ン中間体が生成し, 電子供与性の弱いモノマーの場合, シラシカル中間体が生成すると提唱している1).そこ で, MeOSt とCHDの電子供与性を評価するために, ${ }^{13} \mathrm{C} \mathrm{NMR}\left(\mathrm{CDCl}_{3}\right)$ を測定した. MeOSt のビニル基お よびCHD のオレフィン炭素のケミカルシフト値は，そ れでれ $111.4 \mathrm{ppm}$ および $126.2 \mathrm{ppm}$ と得られ，CHD が MeOSt より電子供与性が弱いことを示している．した がって, CQM/MeOSt 系と CQM/CHD 系の無触媒重 合において生成する中間体の違いは，MeOSt と CHD の電子供与性の違いによると考えられる.

\section{4 結論}

種々の条件で CQM とCHD との無触媒重合を行い, その反応生成物を詳細に解析することにより，無触媒重 合反応機構について検討した。 その結果, CQM と CHD との無触媒重合では, Diels-Alder反応による $\mathrm{CQM}$ と CHDの $1: 1$ 付加体とシラシカカル中間体が生 成し, シラシカル中間体を経由した共重合が進行するこ とにより CQM と CHD の交互共重合体が生成する反応 機構であることが明らかとなった.

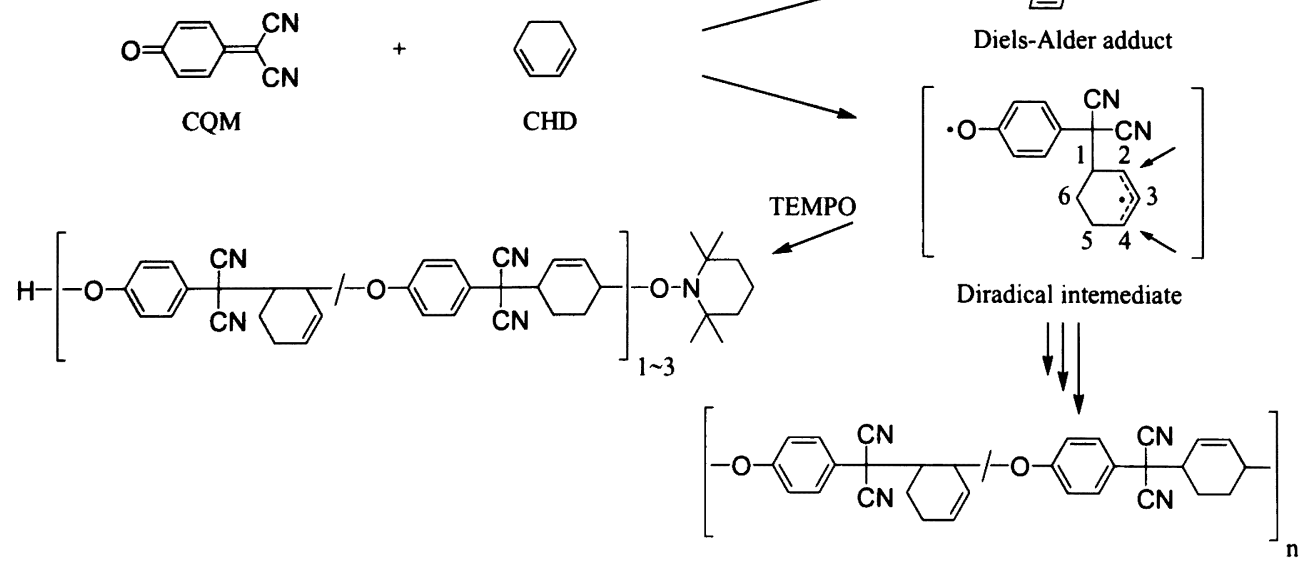

Scheme 3. Spontaneous polymerization mechanism of CQM with CHD. 


\section{文献}

1) H. K. Hall, Jr., Angew. Chem. Int. Ed., 22, 440 (1983).

2) H. K. Hall, Jr. and A. B. Padias, Acc. Chem. Res., 23, 3 (1990).

3) H. A. Clever, G. Wang, W. C. Mollberg, A. B. Padias, and H. K. Hall, Jr., J. Org. Chem., 57, 6837 (1992).

4) Y. Li, A. B. Padias, and H. K. Hall, Jr., J. Org. Chem., 58, 7049 (1993).

5) S. Iwatsuki, T. Itoh, and K. Horiuchi, Macromolecules, 11, 497 (1978).

6) S. Iwatsuki and A. Kondo, J. Org. Chem., 47, 1965 (1982).

7) S. Iwatsuki, T. Itoh, and I. Yokotani, Macromolecules, 16, 497 (1983).

8) S. Iwatsuki, T. Itoh, T. Iwai, and H. Sawada, Macromolecules, 18, 2726 (1985).
9) H. K. Hall, Jr., T. Itoh, S. Iwatsuki, A. B. Padias, and J. E. Mulvaney, Macromolecules, 23, 913 (1990).

10) Y. Mitsuda, T. Fujikawa, T. Uno, M. Kubo, and T. Itoh, Macromolecules, 36, 1028 (2003).

11) Y. Mitsuda, S. Kawaguchi, T. Uno, M. Kubo, and T. Itoh, Macromolecules, 37, 1251 (2004).

12) J. A. Hyatt and J. J. Krutak, J. Org. Chem., 42, 169 (1977).

13) S. Yamamoto, F. Sanda, and T. Endo, Macromol. Chem. Phys., 201, 1696 (2000).

14) Y. Gendreau and J. F. Normant, Tetrahedron, 35, 1517 (1979).

15) H. K. Hall, Jr. and A. B. Padias, Acc. Chem. Res., 30, 322 (1997).

Spontaneous Polymerization Mechanism of 7,7-Dicyanobenzoquinone Methide with 1,3-Cyclohexadiene

Shuji KawaguchI, ${ }^{* 1}$ Yukihiro Mitsuda, ${ }^{* 1}$ Takahiro Uno, ${ }^{* 1}$ Masataka Kubo, ${ }^{* 1}$ and Takahito IтoH ${ }^{* 1}$

${ }^{* 1}$ Department of Chemistry for Materials, Faculty of Engineering, Mie University (Kamihama-cho, Tsu, Mie 514-8507, Japan)

Spontaneous polymerization of 7,7-dicyanobenzoquinone methide (CQM) with 1,3-cyclohexadiene (CHD) was investigated. The spontaneous reactions gave alternating copolymers of CQM with CHD, where CHD units were incorporated in 1,2-and 1,4-addition structures, as hexane-insoluble products and a Diels-Alder adduct of CQM with CHD as hexane-soluble product. Addition of acetic acid to the spontaneous polymerization system did not affect the composition and distribution of products. On the other hand, the spontaneous polymerization in the presence of 2,2,6,6-tetramethylpiperidine-1-oxyl (TEMPO) gave a low molecular weight alternating copolymer with TEMPO at the terminal end as hexane-insoluble product and a 1:1:1 adduct as hexane-soluble product. It was concluded from these results that the spontaneous polymerization of $\mathrm{CQM}$ with $\mathrm{CHD}$ proceeds via a diradical intermediate.

KEY WORDS 7,7-Dicyanobenzoquinone Methide / 1,3-Cyclohexadiene/Spontaneous Polymerization / Alternating Copolymer / Diradical Intermediate /

(Received December 1, 2003: Accepted January 7, 2004)

[Kobunshi Ronbunshu, 61(4), 263-268 (2004)] 